\title{
Folding Style of the Kuh-e Siah Anticline in the Sarvestan Area, Interior Fars, Zagros, Iran
}

\author{
Zahra Maleki*, Fatemeh Jahadgar \\ Department of Geology, Science and Research Branch, Islamic Azad University, Tehran, Iran \\ Email: ${ }^{*}$ z.maleki@srbiau.ac.ir
}

Received 1 May 2015; accepted 23 August 2015; published 26 August 2015

Copyright (C) 2015 by authors and Scientific Research Publishing Inc.

This work is licensed under the Creative Commons Attribution International License (CC BY). http://creativecommons.org/licenses/by/4.0/

(c) (i) Open Access

\section{Abstract}

The Kuh-e Siah anticline is located in the Sarvestan area of the Fars province (186 $\mathrm{km}$ to Persian Gulf) and Interior Fars sub basin. This anticline is a fault bend fold and is located in the Sarvestan fault zone with Northwest-Southeast trend. The Sarvestan fault zone has caused main deformation by dextral strike slip activity in southern part of the Zagros fold-thrust belt. The main aim of this paper is to determine of fold style elements and folding pattern of the Kuh-e Siah anticline. This paper presents part of the results of a regional study of the Fars province in the Zagros Simply folded belt, based on original fieldwork, satellite images, structural sections, geological maps and well data. In addition, we used some software as Global Mapper and Tectonics FP for prepared some data. Folds, which are close sideways, are neutral and these require special attention. It is remarkable that, in all sections of the Kuh-e Siah anticline, fold type is close and in the middle part of the anticline, fold type is different with other parts. In the middle part, fold type is uprightmoderately gently plunging. On the other hand, in northwestern and southeastern parts fold type is similar together. These results maybe show that fold style follow that fold sigmoidal shape that created with two-fault segment of the Sarvestan fault zone in the study area. Therefore, it seems that the Kuh-e Siah anticline has suffered high deformation in the Sarvestan fault zone and this fault zone has created shear zone.

\section{Keywords}

Zagros, Iran, Kuh-e Siah Anticline, Fold Style, Sarvestan Fault

\section{Introduction}

The Study area is located in the Zagros Simply Folded Belt of Iran and in the interior Fars sub-basin [1] [2] ${ }^{*}$ Corresponding author. 
(Figure 1). The Zagros Fold-thrust belt is home to one of the largest petroleum producing reservoirs in the world [3]. This belt is recognized by the NW-SE trending parallel anticlines that verge to the SW in a $6-12 \mathrm{~km}$ cover sequence [3] [4]. The Simply Folded Zone (SFZ) is orientation as the southwesterly boundary of the Zagros orogen near the Persian Gulf.

Based on Physiographic-tectonic zoning map of Iran's (sedimentary basins of Iran), the study area is located in the Zagros-East Taurus hinterland [5] (Figure 2). In this region, the folds are capped by the Oligocene Asmari Limestone [3] [6] [7] and the sedimentary cover sequence is floored by the Hormuz Formation, a dominantly evaporate formation, which acts as a major decollement horizon [8]-[10].

The Kuh-e Siah anticline is located in the Sarvestan area of the Fars province (186 km to Persian Gulf) and Interior Fars sub basin. This anticline has North-Northwest, South-Southeast trend. The geometry of anticlines in the Zagros fold-thrust belt is affected by type of deformation and mechanical behavior of stratigraphic units specially detachment units. In this belt, detachment units are important for controlled folding pattern [11] [12]

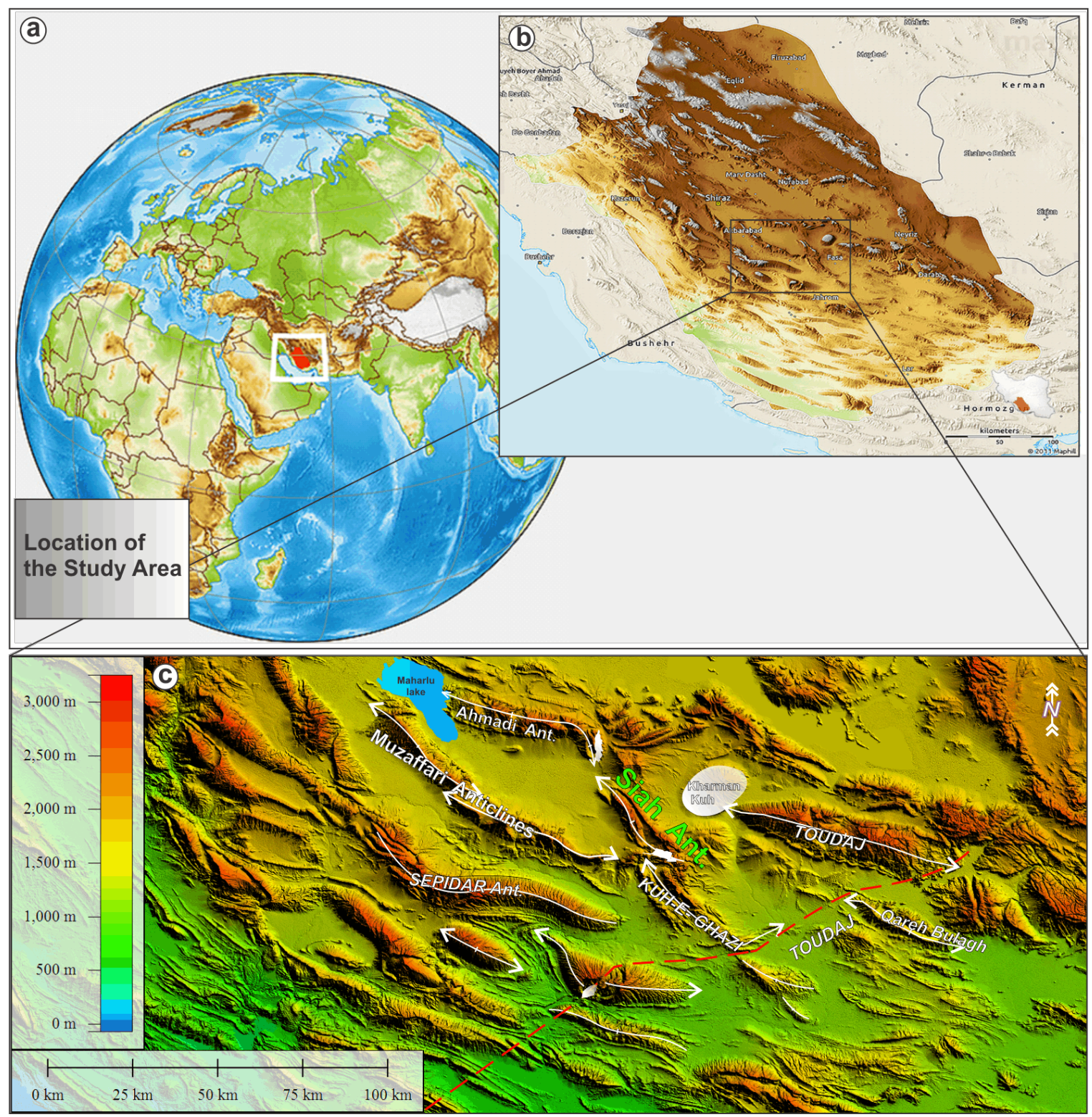

Figure 1. Landsat Satellite image shows the study area and location of the Kuh-e Siah anticline in the Zagros fold-thrust belt, southern of Iran. Inset Satellite image (a) shows location of the study area with white framework in the Middle East. Also, in this figure shows location of the Kuh-e Siah salt plug in the study area. 


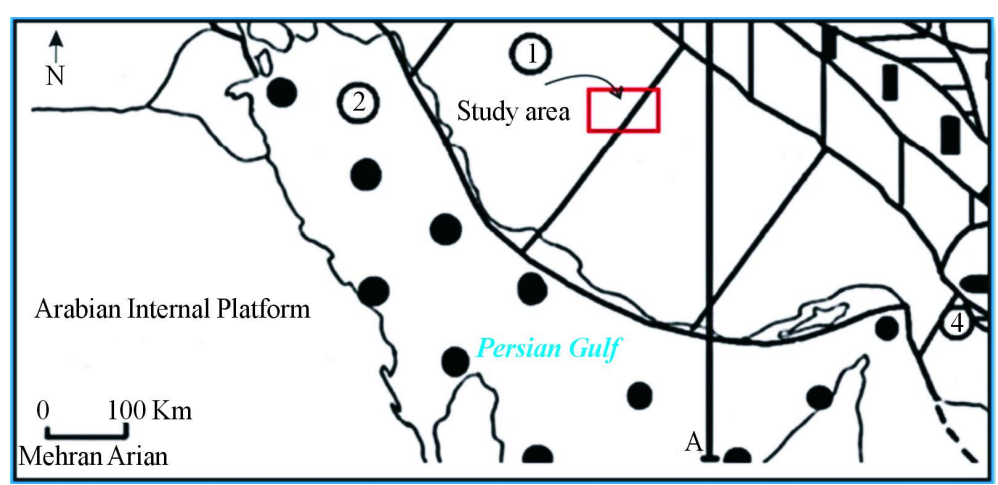

Figure 2. Physiographic-tectonic zoning map of Iran's sedimentary basins Iran showing the study area in the Zagros-East Taurus hinterland [5].

[13]. The basal Hormuz and other detachments play important roles for the style of the Zagros Fold-thrust belt structures. One of the main detachment units in the study area is Dashtak formation that belongs to Kazeron group. This formation is composed of evaporate, shale and dolomite units. This formation has important role on folding geometry especially in the Fars region. Also, other detachment formations in this area are Kazdomi and Gachsaran formations that play important roles on the structural style of area.

In the Zagros fold-thrust belt, structural analysis of surface and subsurface data shows that salt layers such as Cambrian Hormuz and the Miocene Gachsaran have direct control on the structural style [11]. Until now, In the Zagros fold-thrust belt, many studies have been done on to variation of structural style and effects of detachment folding on folding pattern [12]-[13]. Also, many researchers discussed basement involvement and reactivated structures in the Zagros fold-thrust belt and its roll on folding pattern, e.g. [10] [14]-[17]. Several researchers emphasized on variation of folding style based on variation of fold style elements [18]-[23]

For the first time, O’Brien (1950) [24] was the first one to show the effects of detachment layers on folding process and other researchers have discussed about this too, e.g. [25]-[29].

In the Fars region, the Kuh-e Siah Anticline has sigmoidal structure affected by activity of faults in the study area. The Kuh-e Siah anticline is located in the Sarvestan area of the Fars province (186 km to Persian Gulf) and Interior Fars sub basin. This anticline has North-Northwest, South-Southeast trend.

The Kuh-e Siah anticline has rotation of the fold axis from Northwest to Southeast. This anticline is bounded from north - northeast by the Kuh-e Ahmadi anticline, from South by the Kuh-e Qazi anticline from East by the Tudej anticline and from west by the Muzaffari anticline (Figure 1). The Kuh-e Siah anticline is an asymmetric structure, which has $26 \mathrm{~km}$ length and $20 \mathrm{~km}$ width (Figure 3). Based on Setchell et al., (2007) [25], the Kuh-e Siah anticline is a fault bend fold and in Southeastern of this anticline, cropping out salt diaper with $8 \mathrm{~km}$ length and $3 \mathrm{~km}$ width (Figure 3). Around the salt diaper area, in southwestern flank of this anticline has destroyed.

Description of fold geometry is important because they allow comparisons within and between folds and pattern-recognition in addition to occurrence and distribution of fold systems. The main aim of this paper is to determine of fold style elements and folding pattern of the Kuh-e Siah anticline.

\section{Material and Methods}

This paper presents part of the results of a regional study of the Fars province in the Zagros Simply folded belt, based on original fieldwork, satellite images, thin sections, geological maps and well data. Our fieldwork in the study area and some data such as geological maps and geological regional data were prepared and provided by the National Iranian Oil Company (NIOC). In the study area, not provided seismic data to analysis and discuss the structural features by Oil Companies in this region. All geological reports have studied and all the elements of fold style have calculated and analyzed. We used fold style elements analysis methods (description of folds) based on [30]-[33]. We used Tectonics FP software for prepared and analyzed Stereoplots of the Kuh-e Siah anticline. Also, we used Global Mapper Software forprepared3D SRTM of the study area and 3D Path Profile (along cross sections) based on Global Mapper Software. 3D SRTM prepared based on Digital Elevation Model (DEM) and geological map of study area (published by the National Oil Company and the Geological Survey of Iran). 


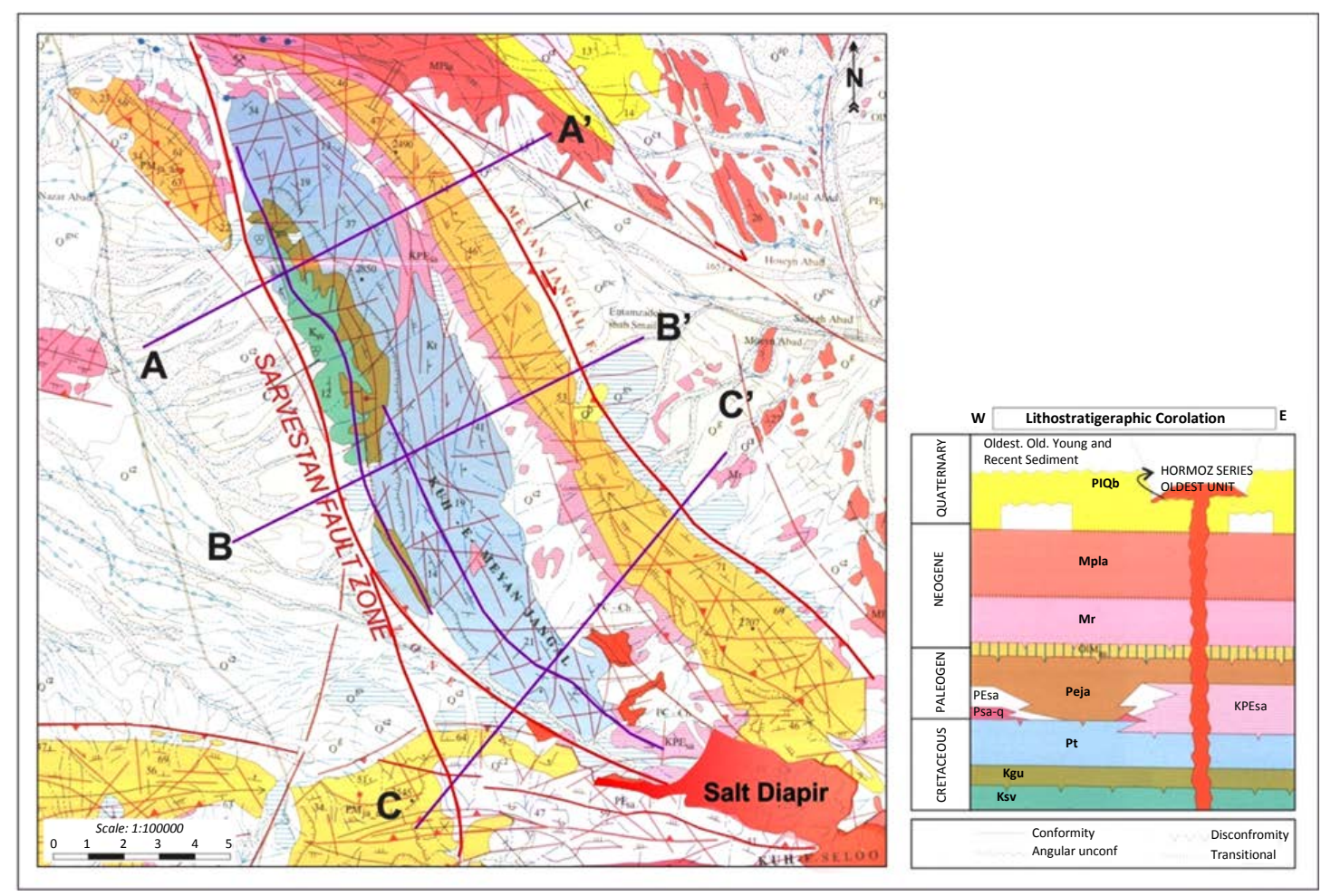

Figure 3. Geological map of the Kuh-e Siah anticline and related salt diapir in the study area. Modified after [35].

\section{Geological Setting and Stratigraphy}

In this paper, the Study area is located in the Zagros orogenic belt. The Zagros fold and thrust belt was formed by collision of two tectonic plates the Eurasian or Iranian and Arabian Plates. In this belt, the Fars region, based on geological fancies units perpendicular to Zagros belt was divided into the interior Fars, coastal Fars and sub-coastal Fars sub-basins [1] [2] and the study area is located in the Interior Fars sub-basin. This area is easily recognized by the NW-SE orientation parallel anticlines that verge to the SW in a 6 - 12 km cover sequence [3] [28] [29].

In the Zagros fold-trust belt, the oldest known stratigraphic unit with 2000 - 1000 meters thickness estimated as Hormuz Series [34] [35] and is exposed in the form of salt domes in the Fars region. Structures in this area have complications and the oldest stratigraphy unit that outcropped in the Kuh-e Siah anticline on the surface belongs to Hormuz Series (salt plug). The age of Hormuz Series is Pre-Cambrian-Cambrian (Figure 3).

Anticlines outcropping stratigraphic units in the most of structures Fars region often include Upper Cretaceous stratigraphic units (Maes Tryshtyn-Campanian to the present) and in the sub-coastal Fars region, includes the Lower Cretaceous stratigraphic units (Neocomian to the present). The youngest formations that outcrop in the study area are Aghajari, Bakhtiari, and Razak Formations. Also, in the interior Fars sub-basin, the oldest outcrops is Hormuz Series observed in the Kuh-e Siah, Kuh-e Qazi and Surmeh anticlines form of salt domes [1] [2] [22].

The Kuh-e Siah anticline is located in the West, North-West of the Jahrom city in the Fars province (148 km to Persian Gulf). This anticline has North-Northwest, South-Southeast trend. This anticline is bounded from North-Northeast by the Kuh-e Ahmadi anticline, from South by the Kuh-e Qazi anticline from East by the Tudej anticline and from west by the Muzaffari anticline (Figure 1).

The Kuh-e Siah anticline is an asymmetric structure, which has $26 \mathrm{~km}$ length and $20 \mathrm{~km}$ width (Figure 3). Based on Setchell et al., (2007) [25], this anticline is a fault bend fold. In Southeastern part of this anticline, salt diaper, cropping out with $8 \mathrm{~km}$ length and $3 \mathrm{~km}$ width (Figure 3, Figure 4). Around the salt diaper area, in southwestern flank of this anticline has destroyed. The Coordinates of Kuh-e Siah salt plug (belongs to the Kuh-e Siah anticline) is located between $53^{\circ} 42^{\prime}$ to $53^{\circ} 50^{\prime}$ longitudes and $28^{\circ} 03^{\prime}$ to $28^{\circ} 99^{\prime}$ latitudes. The Kuh-e Siah salt plug has $8 \mathrm{~km}$ length and $3 \mathrm{~km}$ width (Figure 4). Based on satellite images, total Shape of salt plugs 

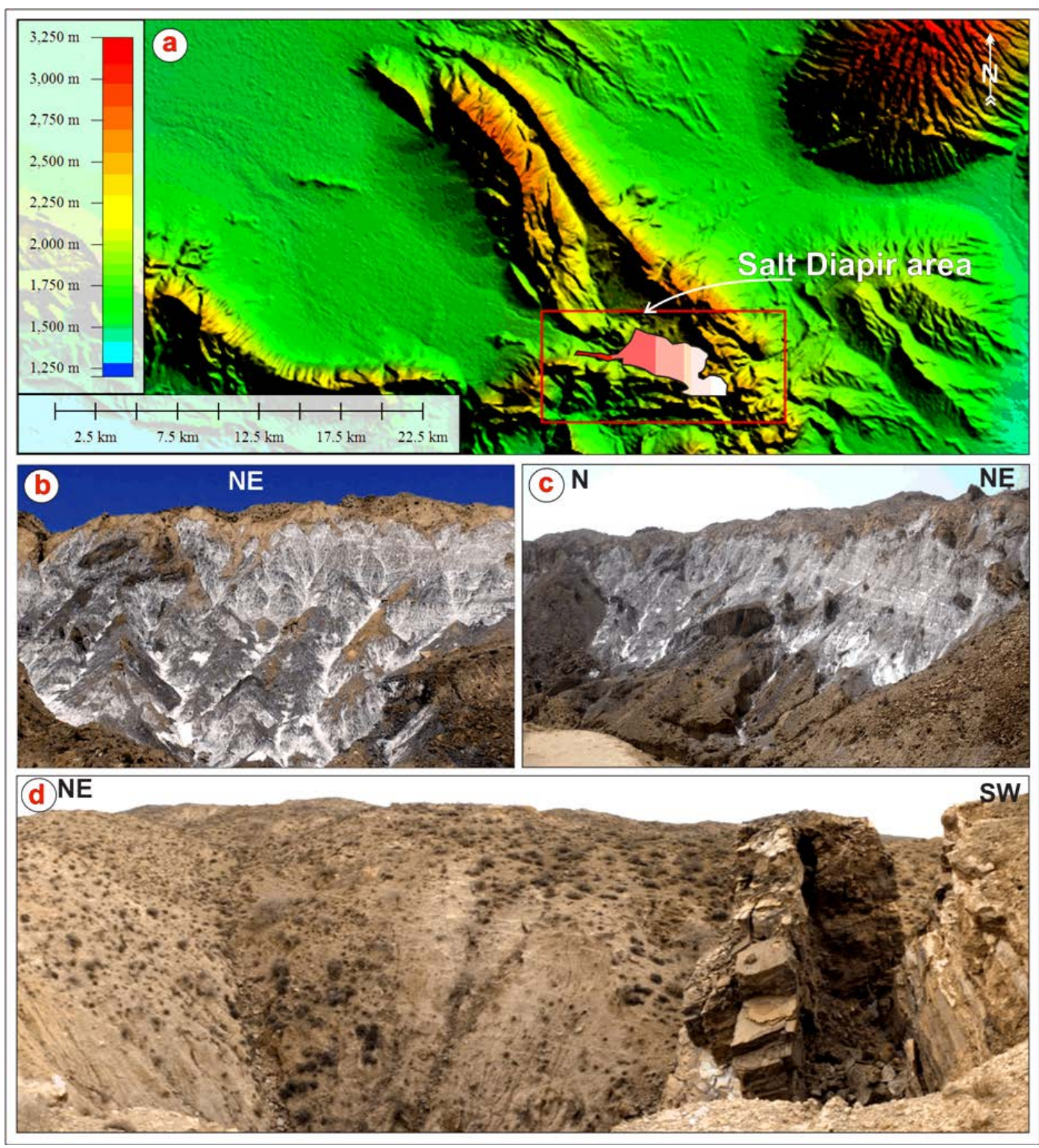

Figure 4. (a) 3D SRTM image (based on Digital Elevation Model (DEM)) of the Kuh-e Siah anticline and their salt diapir. (b), (c) view of the Kuh-e Siah salt diapir, (d) view of the Asmari-Jahrom formation in the study area.

specially the satellite images is asymmetric (NE-SW trending longer axis).

\section{Tectonic}

The Kuh-e Siah anticline is a box fold with North-Northwest, South-Southeast trend. This anticline is located in the Sarvestan fault zone with Northwest-Southeast trend. The Sarvestan fault zone has caused main deformation by dextral strike slip activity in southern part of the Zagros fold-thrust belt.

Stratigraphic units that exposed on the surface of this anticline are Bangestan group Formations, Gourpi, Tarbour, Sachon, Asmari-Jahrom and Razak Formations (Figure 3). This anticline has different trend into other anticlines in the Sarvestan area. The Kuh-e Siah anticline has sigmoidal shape in the dextral strike slip Sarvestan fault area. It seems that, this anticline is located in the shear zone, which created with two segment of the Sarvestan fault. It seems that activity of the Sarvestan fault in the forelimb of the Kuh-e Siah anticline caused Late Cretaceous Bangestan group placed front of the Paleocene - Eocene, Asmari-Jahrom Formation in eastern part 
of anticline. The Kuh-e Siah fault in Southern flank affected by Sarvestan fault and in eastern part of this anticline, caused rotation of fold part axis to Southeastern. It seems that cropping out of the salt diapir and activity of the Sarvestan fault in this part, caused change and rotation of the fold axis anticline.

\section{The Description of Folds}

Based on Twiss and Moors (1992) [30], description of fold geometry is important because they allow comparisons within and between folds and allow us to recognize patterns in the occurrence and distribution of fold systems. For example, orogenic belts contain characteristic fold systems: along their flanks are large fold and thrust belts, with little metamorphism, but underlain by decollement and in core zones where intense folding has accomplished, accompanied by high-grade metamorphism under high temperature and pressure. In the thrust-fold regions located parallel to orogenic belts, certain characteristic types of folds tend to develop; the folds themselves are usually cylindrical with horizontal hinges and are composed of largely unmetamorphosed rock. In the foreland, folds tend to be upright and open, while in the hinterland they tend to be isoclinal and inclined/recumbent, with vergence toward the hinterland. At depth, these folds tend to die out at décollements and may be associated with fault-ramp folds, especially toward the foreland [30]. According to Ragan (2009) [31], Folds, which close sideways, are neutral and these require special attention. In this anticline, based on folding angle (range between $118^{\circ}-130^{\circ}$ ), fold type is close. This results show that, type fold in this anticline affected by activity of the Sarvestan strike slip fault and created rotation in the anticline. In fact, close fold type, change of plunge from $\left(02^{\circ}\right.$ to $\left.10^{\circ}\right)$, changes dip of axial plane and prepared stereoplots show that folding style in this anticline affected by the Sarvestan strike slip fault.

\section{Elements of Fold Style}

The style of a fold is the set of characteristic that describe its form. Over years of working with folds, geologists have identified certain features as particularly useful in describing fold and understanding how they develop [30].

\subsection{Symmetry}

A folded surface forms a symmetric fold if in profile, the shape on one side of the hinge is a mirror image of the shape on the other side, and if adjacent limbs are identifiable in length [30]. The study anticline is an asymmetric fold with changed plunge in the north of the western part of fold. The Kuh-e Siah anticline is an asymmetric anticline. In Southern flank dip of layer less than Northern flank. In southern part of the anticline, Northern limb has greater dip of layer (about $90^{\circ}$, vertical layer) than Southern limb. It seems that activity of fault in this area caused this case. This case was affect by Sarvestan Strike slip fault activity.

\subsection{Cylindricity}

The Cylindricity is represented qualitatively on a stereonet by how closely the poles to planes around a fold fit a great circle distribution [30]. The studied anticline is a cylindrical to conical fold with changed plunge in the north of the western part of fold. The output of Tectonics FP software for three parts of the Kuh-e Siah anticline is shown in the Figure 5.

\section{Classification of the Fold}

In this part, based on classification of Rickard (1971) [33] and Ragan (1985) [31], in the different parts of the Kuh-e Siah anticline, type of fold is variable and two types are recognize (Figure 5 and Figure 6). The Rickard diagram (1971) [33] can also be used to bring out additional details about the folds of an area. If the folds progressively change orientation in some direction, or if some aspect of fold. The value of these several graphical schemes for analyzing and displaying the orientation of folds lies in their comprehensiveness.

In this research, the stereoplots show location of axial planes (AP), cylindricity (AC) and Plunge of Fold (P) for three sections of the Kuh-e Siah anticline (Figure 5). Contour plots in stereoplots show that close fold type and in the middle part of the anticline, fold axis has maximum change. In Figure 7, 3D path profiles show that location of these profiles is match along the cross sections in the study area. Based on Ramsay classification (1967) [32], type fold in the Kuh-e Siah anticline in sections A-A' and C-C' is upright-sub horizontal but in 


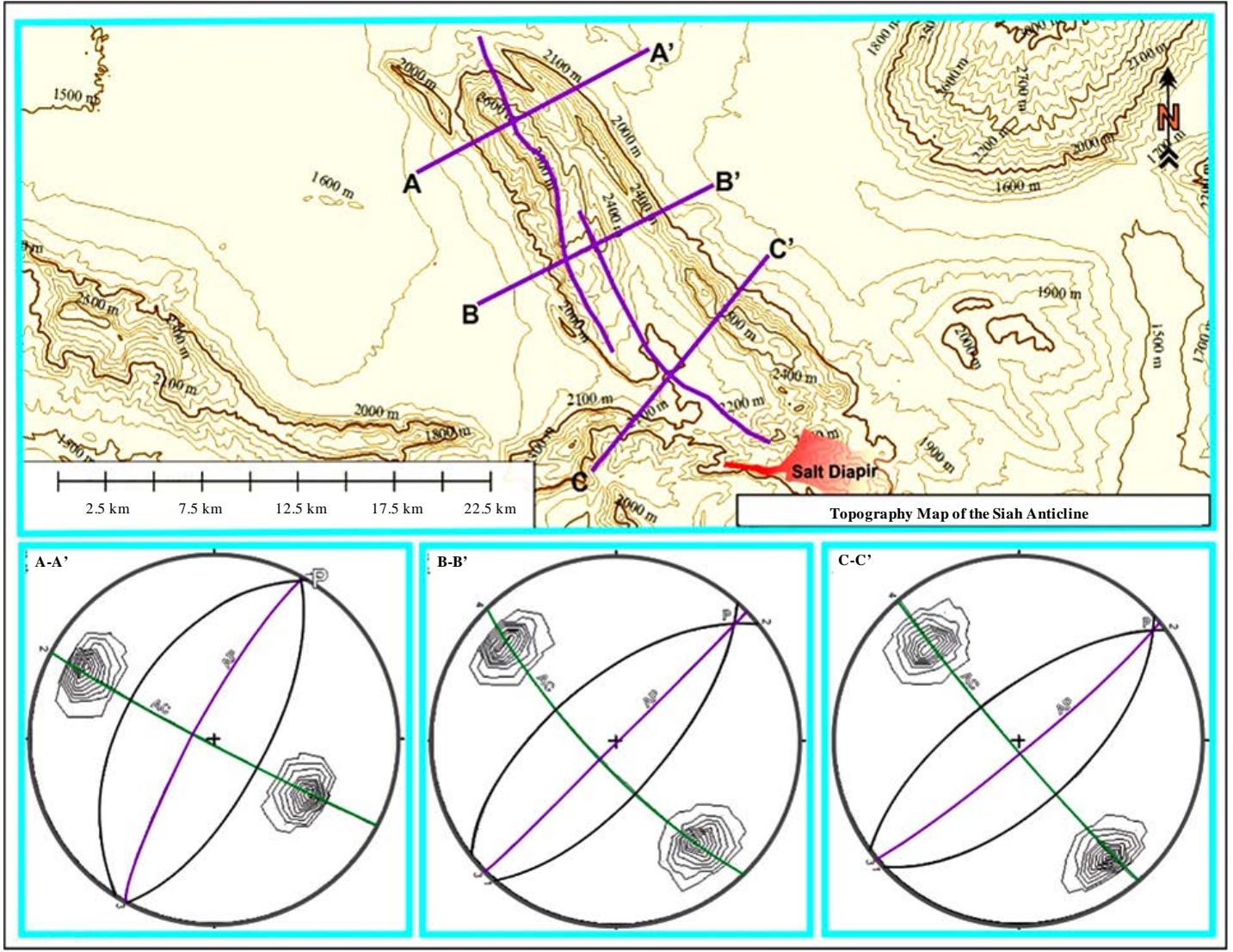

Figure 5. Stereoplots show axial planes (AP), cylindricity (AC) and Plunge of Fold (P) for three sections of the Kuh-e Siah anticline (based on [30]).

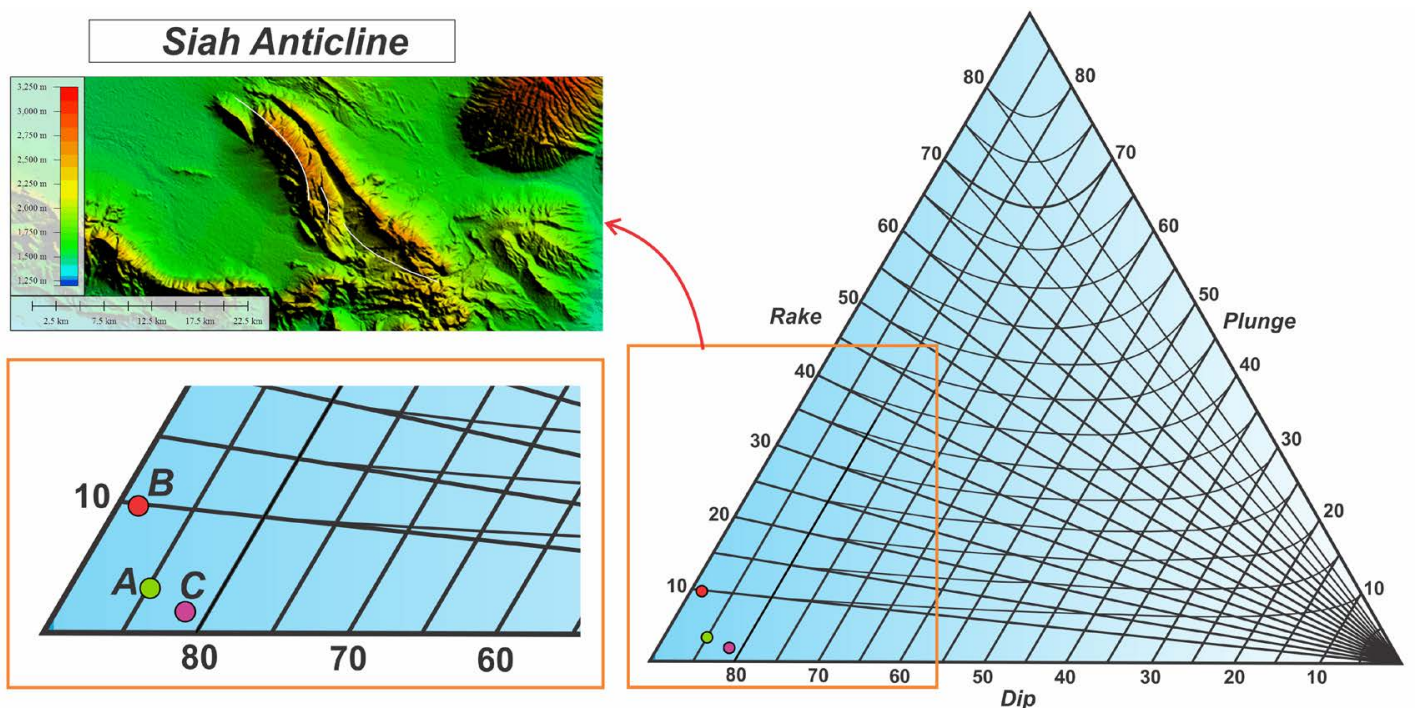

Figure 6. Triangle form diagram show that type of fold in three sections of the Kuh-e Siah anticline, based on [33].

section B-B' is upright-moderately gently plunging. In addition, in northwestern and southeastern parts fold type is similar together. The 3D profiles of the Kuh-e Siah anticline along with study cross sections is shown in the Figure 7. It seems that study anticline has suffered more deformation in the middle part. According to sigmoidal shape of the Kuh-e Siah anticline, it seems that this anticline has affected by shear zone. This shear zone probably 


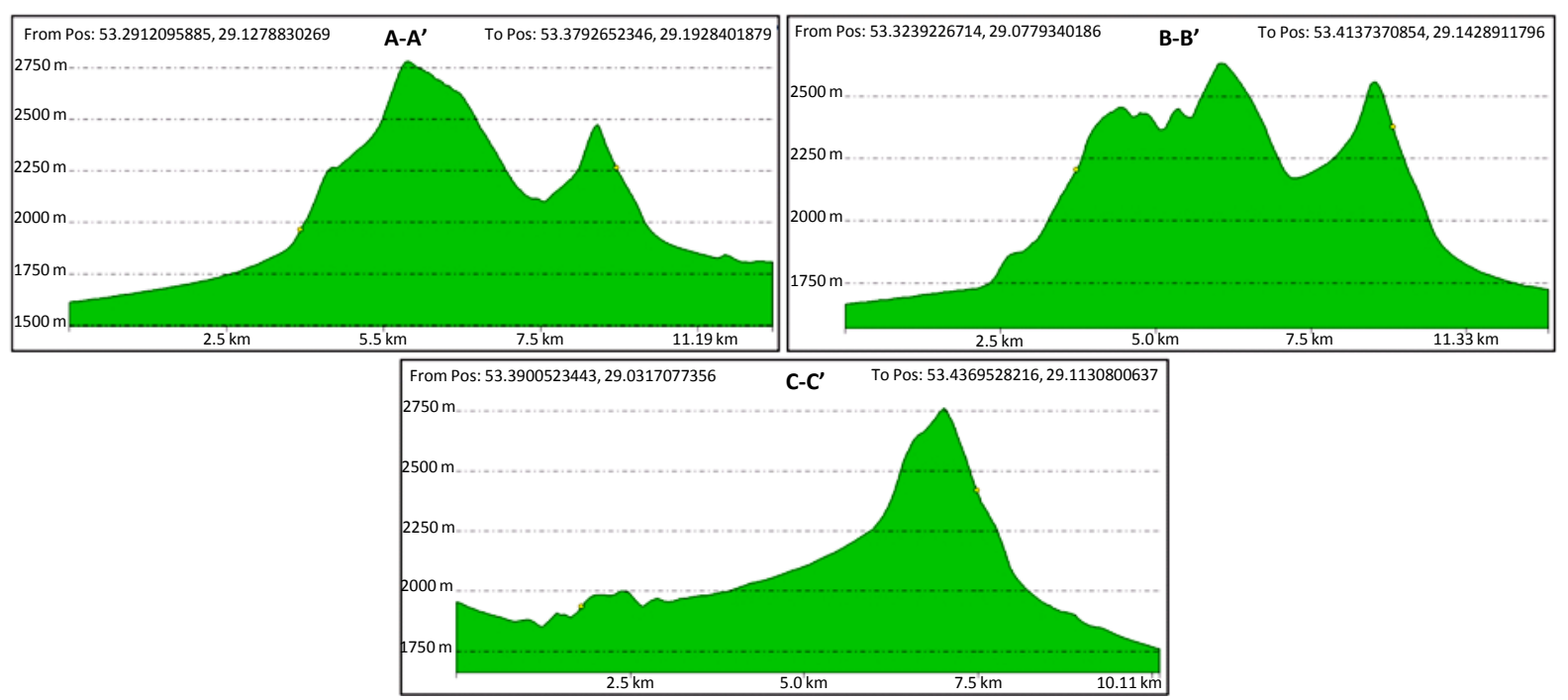

Figure 7. 3D path profiles of the Kuh-e Siah anticline along withstudy cross sections.

has created by the Sarvestan dextral strike slip fault zone.

\section{Conclusions}

Type fold in the Kuh-e Siah anticline in sections A-A' and C-C' is upright-sub horizontal but in section B-B' is upright-moderately gently plunging. In addition, in northwestern and southeastern parts fold type is similar together. These results maybe show that fold sigmoidal shape created with two segment of the Sarvestan fault zone in the study area.

Folds, which close sideways, are neutral and these require special attention. Based on this case, in all sections of the Kuh-e Siah anticline, fold type is close and in the middle part of the anticline, fold type is different with other parts. In this part, fold type is upright-moderately gently plunging. On the other hand, in northwestern and southeastern parts fold type is similar together. These results maybe show that fold style follow that fold sigmoidal shape that created with two-fault segment of the Sarvestan fault zone in the study area. Therefore, it seems that the Kuh-e Siah anticline has suffered high deformation in the Sarvestan fault zone.

At finally, it seems that study anticline has suffered more deformation in the middle part. According to sigmoidal shape of the Kuh-e Siah anticline, it seems that this anticline has affected by shear zone. This shear zone probably has created by the Sarvestan dextral strike slip fault zone.

\section{Acknowledgements}

The authors acknowledge the Department of geology, Islamic Azad University, Science and Research branch, Tehran, Iran for funded this project. In addition, we thank Vice-President for Research in Science and Research branch, Tehran.

\section{References}

[1] Beydoun, Z.R., Hughes Clark, M.W. and Stoneley, R. (1992) Petroleum in the Zagros Basin; a Late Tertiary Foreland Basin Overprinted onto the Outer Edge of a Vast Hydrocarbon-Rich Palaeozoic-Mesozoic Passive Margin Shelf. American Association of Petroleum Geologists, Memoir, Vol. 55, 309-339.

[2] Motiei, H. (1993) Stratigraphy of Zagros. Treatise on the Geology of Iran. Ministry of Mines and Metals, Geological Survey of Iran, Tehran.

[3] Molnar, M. (2006) Tertiary Development of the Zagros Mountains. Geol 418—Earth History.

[4] Furst, M. (1976) Tektonik und Diapirismus der östlichen Zagros ketten. Zeitschrift der Deutschen Geologischen Gesellschaft, 127, 183-225.

[5] Arian, M. (2013) Physiographic-Tectonic Zoning of Iran’s Sedimentary Basins. Open Journal of Geology, 3, $169-177$. 
http://dx.doi.org/10.4236/ojg.2013.33020

[6] Blance, E.J.-P., et al. (2003) Structural Styles in the Zagros Simple Folded Zone, Iran. Journal of the Geological Society, 160, 401-412. http://dx.doi.org/10.1144/0016-764902-110

[7] Burberry, C.M., Cosgrove, J.W. and Liu, J.G. (2008) Spatial Arrangement of Fold Types in the Zagros Simply Folded Belt, Iran, Indicated by Landform Morphology and Drainage Pattern Characteristics. Journal of Maps, 4, 417-430. http://dx.doi.org/10.4113/jom.2008.97

[8] Alavi, M. (2004) Regional Stratigraphy of the Zagros Fold-Thrust Belt of Iran and Its Proforeland Evolution. American Journal of Science, 304, 1-20. http://dx.doi.org/10.2475/ajs.304.1.1

[9] Bahroudi, A. and Koyi, H. (2003) Effect of Ductile and Frictional Décollements on Style of Extension. Journal of Structural Geology, 25, 1401-1423. http://dx.doi.org/10.1016/S0191-8141(02)00201-8

[10] Falcon, N. (1974) Southern Iran: Zagros Mountains. In: Spencer, A., Ed., Mesozoic-Cenozoic Orogenic Belts, Geological Society of London, Special Publication, Vol. 4, 199-211. http://dx.doi.org/10.1144/gsl.sp.2005.004.01.11

[11] Letouzey, J. and Sherkati, S. (2004) Salt Movement, Tectonic Events, and Structural Style in the Central Zagros Fold and Thrust Belt (Iran). Proceedings of the 24th Annual GCSSEP, Foundation, Interactions and Bob F. Perkins Research Conference on Salt Sediments Hydrocarbon Prospectivity, 5-8 December 2004, Houston, 535-534.

[12] Sherkati, S. and Letouzey, J. (2004) Variation of Structural Style and Basin Evolution in the Central Zagros (Izeh Zone and Dezful Embayment), Iran. Marine and Petroleum Geology, 21, 535-554.

[13] Sherkati, S., Molinaro, M., Frizon de Lamotte, D. and Lettouzey, J. (2005) Detachment Folding in the Central Eastern Zagros Fold-Belt (Iran): Salt Mobility, Multiple Detachments and Late Basement Control. Journal of Structural Geology, 27, 1680-1696. http://dx.doi.org/10.1016/j.jsg.2005.05.010

[14] Alavi, M. (2007) Structures of the Zagros Fold-Thrust Belt in Iran. American Journal of Science, 307, 1064-1095. http://dx.doi.org/10.2475/09.2007.02

[15] Barzegar, F. (1994) Basement Fault Mapping of Zagros Folded Belt (S. W. Iran) Based on Space-Born Remotely Sensed Data. Proceeding of the 10th Thematic Conference on Geologic Remote Sensing: Exploration, Environment and Engineering, San Antonio, 9-12 May 1994, 455-466.

[16] McQuillan, H. (1991) The Role of Basement Tectonics in the Control of Sedimentary Facies, Structural Patterns and Salt Plug Emplacements in the Zagros Fold Belt of Southwest Iran. Journal of Southeast Asian Earth Sciences, 5, 453463. http://dx.doi.org/10.1016/0743-9547(91)90061-2

[17] Talbot, C.J. and Alavi, M. (1996) The Past of a Future Syntaxis across the Zagros. In: Alsop, G.I., Blundell, D.J. and Davison, I., Ed., Salt Tectonics, Vol. 100, Geological Society, London, 89-109. http://dx.doi.org/10.1144/gsl.sp.1996.100.01.08

[18] Maleki, Z., Arian, M., Solgi, A. and Ganjavian, M.A. (2014)The Elements of Fold Style Analysis in the Khaftar Anticline, Zagros, Iran. Open Journal of Geology, 4, 79-92. http://dx.doi.org/10.4236/ojg.2014.43008

[19] Maleki, Z., Arian, M., Solgi, A. and Ganjavian, M.A. (2013) Sediment Deformations on Strike Slip Fault Blocks and Analogue Modeling: A Case Study of the Nezamabad Fault, Interior Fars, Zagros. Journal of Sciences, 89, 39-51. (In Persian)

[20] Maleki, Z., Arian, M., Solgi, A. and Ganjavian, M.A. (2015) Analysis Elements of Fold Style in the Karbasi Anticline, Interior Fars Region, Zagros. Geosciences, 24, 293-302.

[21] Maleki, Z., Arian, M. and Solgi, A. (2014) Structural Style and Hydrocarbon Trap of Karbasi Anticline, in the Interior Fars region, Zagros, Iran. Solid Earth Discussions, 6, 2143-2167. http://dx.doi.org/10.5194/sed-6-2143-2014

[22] Maleki, Z. (2015) The Unique Folding Style in the Zagros Simply Folded Belt, the Kuh-e Qazi Anticline, South Iran. Open Journal of Geology, 5, 514-526.

[23] Maleki, Z., Arian, M. and Solgi, A. (2015) Folding Pattern in the Fars Province, Zagros Folded Belt: Case Study on the Karbasi and Khaftar Anticlines, Interior Fars, Iran. Solid Earth Discuss, 7, 2347-2379. http://dx.doi.org/10.5194/sed-7-2347-2015

[24] O’Brien, C.A.E. (1950) Tectonic Problems of the Oil Field Belt of Southwest Iran. Proceedings of 18th International of Geological Congress, London, 45-58.

[25] Setchell, C.M., Cosgrove, J.W. and Liu, J.-G. (2007) The Distribution of Fold Types in the Zagros Simply Folded Belt, Iran. Imperial College, London. (Map Scale 1:100000)

[26] Jamison, W.R. (1987) Geometric Analysis of Fold Development in Overthrust Terrenes. Journal of Structural Geology, 9, 207-219. http://dx.doi.org/10.1016/0191-8141(87)90026-5

[27] Mitra, S. (2002) Fold-Accommodation Faults. American Association of Petroleum Geologists Bulletin, 86, 671-693.

[28] Mitra, S.A. (2003) Unified Kinematic Model for the Evolution of Detachment Folds. Journal of Structural Geology, 25, 
1659-1673. http://dx.doi.org/10.1016/S0191-8141(02)00198-0

[29] Suppe, J. (1985) Geometry and Kinematics of Fault-Bend Folding. American Journal of Science, 283, 684-721. http://dx.doi.org/10.2475/ajs.283.7.684

[30] Twiss, R.J. and Moores, E.M. (1992) Structural Geology. W.H. Freeman and Company, New York, 532.

[31] Ragan, D.M. (1985) Structural Geology, an Introduction to Geometrical Techniques. 3rd Edition, John Wiley \& Sons, Inc., 210-215.

[32] Ramsay, J.G. (1967) Folding and Fracturing of Rocks. McGraw-Hill, New York, 568.

[33] Rickard, M.J.A. (1971) Classification Diagram for Fold Orientation. Geological Magazine, 108, 23-26. http://dx.doi.org/10.1017/S0016756800050925

[34] Ala, M.A. (1974) Salt Diapirism in Southern Iran. American Association of Petroleum Geologists Bulletin, 58, 17581770 .

[35] Kent, P.E. (1970) The Salt of the Persian Gulf Region. Leicester Literary and Philosophical Society, 64, 56-88. 